\title{
Letters
}

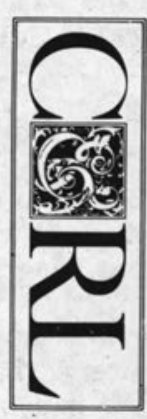

To the Editor:

We take exception to the section in the Bruce R. Kingma and Philip B. Eppard article- "Journal Price Escalation and the Market for Information: The Librarians' Solution" (CERL 53 [Nov. 1992]: 523-35)—which refers to our May 1988 Library Journal article. Kingma and Eppard state that we have "attributed journal prices escalation simply to overly greedy publishers seeking to extract ever greater profit from libraries." Apparently the authors did not carefully read our article.

Although we did say there was a growing belief among librarians that publisher profit was the driving force behind the recent escalation of serial prices, we went on to point out that we recognized there had been a decline in the number of copies printed and that this decline resulted in higher unit costs. We also noted how the information explosion had increased the size and number of journals, and increases in the number of pages published were indeed an important factor. Further, we explained how the selection and review processes, editing, design, and marketing of books and journals cost money. We also went on to say, "As a matter of fact, some of us feel real sympathy' for responsible publishers. We know that the reason the number of pages has increased in some journals is to avoid competition. (Publishers fear that if they don't publish those articles, someone else will.) And we can sympathize with and understand the need to subsidize new publications with the revenues from the older, established, profitable titles, whether or not we agree with these explanations." So, to say that we attribute price escalation simply to greed is shoddy scholarship which misrepresents our views entirely.

\author{
Richard M. Dougherty \\ Professor \\ School of Information and Library Studies \\ University of Michigan \\ Brenda L. Johnson \\ Coordinator for Public Services Technology Use \\ University of Michigan Libraries
}

To the Editor:

I read with interest Peter Hernon and Cheryl Metoyer-Duran's article on literature reviews and inaccurate referencing (CERL 53 [Nov. 1992]: 499-512). However, while scanning the list of references something caught my eye. I noticed that both the volume number and issue date for reference number 22 are incorrect. Given the nature of the article, as well as the nature of the errors, I have concluded that the most likely explanation is that the errors were deliberately inserted for some reason. Perhaps in order to see how many readers would notice them. I do hope this is the case, as it would be quite ironic to find true reference errors in an article about reference errors. Please count me among the readers who did notice.

Robin Babou

Graduate Library Science Student

San Jose State University, Fullerton Campus 
To the Editor:

I enjoyed reading Mark Cyzyk's "Canon Formation, Library Collections, and the Dilemma of Collection Development" (CERL 54 [Jan. 1993]: 58-65). Just when we thought we had a good handle on how to build our collections we discover, much to our chagrin, that our trusted literary canon has shifted. The slippery definition of exactly what our libraries should contain - the much ballyhooed "well-rounded collection" - now seems to be farther than ever from our grasp. This is especially disturbing after we have spent years developing various fancy ways to measure our performance. We had our lists to check, our citations to study, and our circulation statistics to manipulate. Now it seems we are back to the first square.

When all is said and done, it seems that deciding what should go on our shelves still must be done the old-fashioned way-one book at a time through the mysterious process of selection. Even our approval plans cannot save us from this task. I'm not sure we yet know exactly what prompts us to choose one title and not another. Whim or educated guess, how all those pieces of published knowledge fit together to make our collections, and how they got that way, still defies even our most sophisticated research. Collection development is as much an art-squishy though it may be-as it will ever be a science. Keeping up with a moving canon is all in a day's work for those who decide what goes on the shelves.

\section{Ed Goedeken}

Principal Humanities Bibliographer

Iowa State University

To the Editor:

Bryce and Gillian Allen's comparison of librarians' and students' cognitive abilities, in their article "Cognitive Abilities of Academic Librarians and Their Patrons," (CERL 54 [Jan. 1993]: 67-73), can be read to support conclusions different from those presented.

The authors attribute librarians' demonstrated superiority in logical reasoning to innate ability combined with selection in career choice and hiring. It seems to me equally plausible that experience with information seeking has sharpened librarians' reasoning skills. If one posits that a targeted search produces better results than browsing, and that education is compressed experience, the authors' findings make a case for more instruction in the logic of information retrieval rather than, as they suggest, more reliance on point-of-use aid with the mechanics of simple systems.

Similarly, students' apparent preference for simple browse searching may be due less to their greater ability to scan quickly (the authors' explanation) than to uncertainty about what they are looking for. Browsing and haphazard accumulation can mask the problem without contributing to the development of research skill or improvement of the research product.

Of course our information systems should be designed for students, not librarians, but it is worthwhile to consider not only students as they are, but also the goals of their education.

Thelma Freides

State University of New York at Purchase 


\section{Authoritative References}

New Edition!

\section{International}

\section{Books in Print 1993}

Listing of English-Language Trtues Published in Africa, Asta, Austrauia, Canada, Continental.

Europe, Latin America, New Zfaland, Oceania, AND THE REPUBLIC OF IRELAND

$12 \mathrm{TH}$ EDInON

"IBIP bas long been needed by researchoriented libraries... An excellent first step in filling this need."

- Choice

"... simply gets bigger and better each year."

- World Development

$\mathrm{W}_{\text {iti }}$

6,300 publishers, the newly revised 12 th

Edition of International Books in Print

offers more information than ever before -

with completely updated listings and pricing information; more comprehensive title coverage; more detailed publisher and distributor data; and expanded coverage of the Philippines, Israel, Thailand, Singapore, Japan, and the Caribbean.

Part One: Author-Title List

July $1993 \bullet 3-598-22124-\mathrm{X} \bullet 2$ volumes

- c. 2,800 pp. • $\$ 375.00$

Standing Order Price: $\$ 356.25$

\section{Part Two: Subject Guide}

August $1993 \bullet 3-598-22125-8 \bullet 2$ volumes

- c. 2,200 pp. • $\$ 375.00$

Standing Order Price: $\$ 356.25$

Complete Set: Parts One and Two

August 1993 • 3-598-22123-1 • \$700.00

Standing Order Price: $\$ 665.00$
Updated Annually!

\section{International Books in Print on CD-ROM}

The Ihe automated version of this highly acclaimed international reference allows quick and simple access to over 220,000 titles published outside the United States and United Kingdom. Updated annually, this database provides exceptional search features, a choice of three formats and bibliographic data of the highest quality. IBIP on CD-ROM operates in English.

Item \#DIB $110 \bullet$ 1-year subscription

- MS-DOS version • $\$ 950.00$

New Edition!

\section{Publishers' International ISBN Directory 1993/94}

20TH EDTrON

COMPILED AND EDITED IN COLABORATION WTTH THE INTERNATIONAL ISBN AGENCY, BERLIN

$\mathrm{W}_{\text {it }}$ files of the International ISBN Agency, this indispensable tool for the international book trade provides the most comprehensive listings ever - perfect for international ordering, acquisitions, and cataloguing procedures. This updated and expanded edition contains over 250,000 entries from more than 200 countries, including over 267,000 publishers with ISBN prefixes.

August $1993 \cdot 3-598-21602-5 \bullet 3$ volumes

- $\$ 325.00$

Standing Order Price: $\$ \mathbf{3 0 8 . 7 5}$

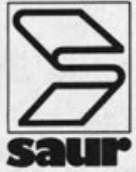

K.G. Saur

A Reed Reference Publishing Company

121 Chanlon Road, New Providence, NJ 07974

1-800-521-8110 


\section{Available Now From ACRL}

Association O COLLEGE \& RESEARCH LIBRARIES

\section{Learning to Teach: Workshops on Instruction}

A practical guide for bibliographic instruction practitioners and program coordinators, this book is a useful and usable training manual. Nine workshops cover the basics with clear, concise discussions of classroom techniques, new technologies, and instruction in a multicultural environment. This collection of workshops is designed to develop fundamental skills and address critical issues in bibliographic instruction.

Learning to Teach: Workshops on Instruction $\$ 24.99$ (\$21.99 ACRL members) $86 p$. ISBN 0-8389-7627-1

\section{Order Department} ALA Publishing Services 50 East Huron Street Chicago, IL 60611-2795
Or call toll-free

1-800-545-2433

FAX: 312-944-2641

Association OF COLLEGE \& RESEARCH LIBRARIES

Association Of COLLEGE \& RESEARCH LIBRARIES

Association Of

COLLEGE

\& RESEARCH

LIBRARIES

Association Of

COLLEGE

\& RESEARCH

LIBRARIES

Association Of

COLLEGE

\& RESEARCH

LIBRARIES

A DIVISION OF THE

AMERICAN IIBRARY ASSOCIATION 